\author{
Dr. sc. Ivan Milotić \\ izvanredni profesor Pravnog fakulteta Sveučilišta u Zagrebu ${ }^{1}$
}

\title{
ARBITRAŽA O RAZGRANIČENJU IZMEĐU ASERIJE I ALVERIJE
}

$U D K: 34$

DOI: $10.31141 /$ zrpfs.2019.56.134.905

Izvorni znanstveni rad

Primljeno: 1. IV. 2019.

Tri terminacijska natpisa koji dokumentiraju razgraničenje Aserije i Alverije bilježe brojne podatke o bitnim elementima procesa u kojemu je ono postignuto. Ti podaci odnose se na institute i tipične pravne izričaje poznate iz rimskoga prava koji su se uobičajeno koristili kod izvansudskog rješavanja spora. Držeći se njihove inskripcije, u ovome članku analiziraju se zabilježeni procesni instituti i pretpostavke rješavanja graničnog spora, poput suda i arbitara, načina postavljanja arbitara, stranaka u sporu, predmeta spora, odlučivanja i, napokon, donošenja pravorijeka. Na temelju postojećih epigrafskih i arheoloških analiza, razgraničenje između Aserije i Alverije sagledava se s pravnoga gledišta, analizom značenja spomenutih pravnih instituta u tome vremenu. To se čini uvažavajući specifičnost provincijske uprave u Dalmaciji i položaja provincijskoga namjesnika koji je i glede Aserije i Alverije, ali i drugih usporedivih peregrinskih zajednica, nastojao da se njihovi međusobni sporovi riješe kako ne bi predstavljali uzroke nemira, a time i zapreke za stabilnu rimsku vladavinu. Inskripcije otkrivaju da se razgraničenje provodilo arbitražno, ali u takvu procesu koji za stranke nije bio dobrovoljan. Stoga se ovdje radi o tipičnu primjeru administrativne/prisilne arbitraže kojoj su se Aserijati i Alveriti morali podvrgnuti.

Ključne riječi: arbitraža, granični spor, terminacijski natpis, Dalmacija, rimsko pravo

\section{UVOD}

Rimljani su uspostavili potpunu vlast u Dalmaciji nakon pokoravanja ovdašnjih plemena u Bellum Batonianum, koji se vodio od 6. do 9. godine (Dzino, 2014., str. 221-222). Iz razdoblja koje je neposredno uslijedilo iz Dalmacije potječe znatan broj epigrafskih svjedočanstava o graničnim sporovima među tim plemenskim zajednicama i načinu njihova rješavanja (Kuntić-Makvić i Šegvić, 1988., str. 49). Ta svjedočanstva zabilježena su na terminacijskim natpisima ${ }^{2}$ i svakako datiraju iz 1. stoljeća. Njihov je sadržaj uklesan na kamenoj podlozi koja se pojavljuje kao gola stijena, neobrađeni kamen, kamena ploča u prirodnom stanju, a dijelom i kao obrađeni kameni stupovi (Smodlaka-Kotur, 1990., str. 31, 32).

1 ivan.milotic@pravo.hr, ORCID ID: orcid.org/0000-0002-6766-8609

2 Terminacijski natpis naziv je za epigrafski spomenik čija inskripcija bilježi granični spor (od lat. terminus $\rightarrow$ granica) i najvažnije činjenice te okolnosti povezane s njegovim rješavanjem. 
Naznačeno epigrafsko gradivo dalmatinske provenijencije nije nepoznato u domaćoj literaturi. Dapače, epigrafski je i filološki obrađeno i odgovarajuće vrednovano te primjereno arheološki kontekstualizirano, a sve je takvo gradivo prikupljeno i razloženo u djelu J. J. Wilkesa naslovljenom Roman Boundary Stones in Dalmatia (Wilkes, 1976., str. 258-274). Natpisi o graničnim sporovima među domorodnim plemenskim zajednicama iz rana prinicipata (1. stoljeće) nisu posebnost Dalmacije. U istome razdoblju i u jednakom ili sličnom teritorijalnopolitičkom kontekstu pojavljuju se ponajviše u Italiji, Hispaniji, Africi, ali i u drugim provincijama Carstva (Campbell, 2000., str. 254).

Ako bi se takvo gradivo iz Dalmacije željelo načelno razvrstati, mogle bi se zamijetiti tri skupine natpisa. Prvoj pripadaju oni koji sadržavaju inskripciju s opisom spora i međa, drugoj natpisi koji dokumentiraju uspjeh u takvom sporu, a trećoj natpisi koji iscrpnije bilježe kako sâm spor tako i različite procesne mehanizme te institute kojima je on riješen (Elliot, 2004., str. 26). Već i površno iščitavanje tih natpisa upućuje na to da je njihov sadržaj prevladavajuće pravni, da sadržava tehničko latinsko nazivlje koje tipično pripada području rješavanja sporova u rimskom pravu te, napokon, da se pravni izričaji tih natpisa pojavljuju u toj mjeri ujednačeno da se odmah može pomisliti kako su izrađeni prema unaprijed zadanim predlošcima (Milotić, 2011., str. 217-232). Premda su i strukturom i sadržajem u znatnoj mjeri shematizirani (stoga jer su se vjerojatno oslanjali na jednak ili sličan predložak), s pravnoga gledišta među spomenutim natpisima dalmatinske provenijencije izrazito se ističu tri terminacijska natpisa koji potječu s tri različita područja u rimskoj Liburniji, a pritom dokumentiraju isti pravni akt - razgraničenje između Aserije i Alverije.

Razgraničenje tih dviju domorodnih (predrimskih) zajednica provedeno je u ranoj fazi Vespazijanove vladavine, između 69. i 70. godine, u doba kada je namjesnik Dalmacije bio Marko Pompej Silvan. Ono nije ostalo nezamijećeno u literaturi. Prije tri desetljeća epigrafski i povijesno najiscrpnije obradile su ga B. Kuntić-Makvić i M. Šegvić (Kuntić-Makvić i Šegvić, 1989., str. 49-62), a postoje i drugi relevantni osvrti na njega (Wilkes, 1976., str. 262, br. 11; Čače, 2003., str. 22-24, br. 3-5; Milotić, 2018., str. 334). Ono što izrazito izdvaja ta tri epigrafska svjedočanstva od 40-ak drugih terminacijskih natpisa iz Dalmacije - što je i glavni razlog njegove analize u ovome radu - jest njegov pravni sadržaj. Oni se ističu jer u razmjerno kratkoj inskripciji dokumentiraju niz instituta, načela, koncepata i izričaja, ali i trendova u rimskom klasičnom pravu povezanih sa situacijama kada se spor rješavao izvansudski, tj. arbitražno (arbitrium/arbitratus), ali uz određen utjecaj rimske javne vlasti.

U ovome radu analizirat će se stoga samo pravna dimenzija razgraničenja između Aserije i Alverije. Kada se sve sagleda, čini se da je to posebno opravdano jer, premda natpisi sadržavaju i određene povijesne naznake, ipak su oni prvotno imali pravnu funkciju jer bilježe čisto pravna pitanja poput spora, postupka njegova rješavanja, sudaca, stranaka u sporu i odluke kojom je okončan. Pravno vrednovanje tih natpisa poduzet će se na temelju analize zabilježenih pravnih instituta i tipično 
pravnotehničkih izričaja, ali i njihovim stavljanjem u kontekst klasičnog rimskog prava (otkada natpisi datiraju) te nužnog dovođenja u svezu sa shvaćanjima o arbitrium izraženima u relevantnim rimskih izvorima.

\section{SADRŽAJ NATPISA O RAZGRANIČENJU ASERIJE I ALVERIJE I NJEGOVA DATACIJA}

S epigrafskoga gledišta razgraničenje između Aserije i Alverije ističe se i time što je ono potvrđeno na više natpisa koji su pronađeni na međusobno udaljenim lokacijama. To je jedinstveni i jedini siguran primjer takva slučaja u Dalmaciji (Kuntić-Makvić i Šegvić, 1988., str. 49). Potreba za njegovim trostrukim dokumentiranjem na trima različitim lokacijama dovoljno je znakovita i dokaz je o važnosti razgraničenja dviju susjednih peregrinskih zajednica, ali i naznaka o njegovu održanju i mjerodavnosti za plemenske zajednice Aserijata i Alverita u dužem razdoblju. Njihove inskripcije sadržajno su analogne, ${ }^{3}$ a za potrebe ovoga članka koristit će se rekonstrukcija trećega (najkasnije pronađena) svjedočanstva koje potječe s Bribirske glavice. Razlog njegova odabira leži u povoljnoj činjenici što je s epigrafskog gledišta odgovarajuće rekonstruirana njegova inskripcija, a istovremeno je s arheološkoga gledišta od svih najiscrpnije obrađen u literaturi, što omogućuje da se u ovome radu posvetimo samo njegovim pravnim odrednicama. Rekonstruirani tekst natpisa s Birbirske glavice, prema čitanju B. Kuntić-Makvić i M. Šegvić (Kuntić-Makvić i Šegvić, 1988., str. 52) glasi:

[Ti(berius) Cl]audius Epetinus [C(aius) A]vilius Clemens,

[L(ucius) Coeliu]s Capella, P(ublius) Raec

ius Libo, P(ublius) Valeri]us S[ec]und[us]

[iudice]s dati a M(arco) Pomp(eio)

Silvano leg(ato) Aug(usti) pro pr(aetore)

[inter rem $p$ (ublicam) Asseriatium

et rem p(ublicam) Alveritarum in [re]

praesenti [pe]r [s]e[nt]enti[am] s[uam]

[determ]inaverunt.

3 Prvi natpis, iz Dobropoljaca, pronađen na brežuljku Smrdeljica kod Podgrada nedaleko Benkovca, glasi: Ti(berius) [Cl]audius ... / C(aius) Avillius Clemen[s] / L(ucius) Coelius Capella P(ublius) / Raecius Libo P(ublius) Valeri / us Secundus iudices / dati a M(arco) Pompeio Silva / no leg(ato) Aug(usti) pro / pr(aetore) inter / rem p(ublicam) Asseriatium et rem p(ublicam) Al / veritarum in re praesenti per / [sententi]am suam determina / verunt CIL III, 9938. Za literaturu vidi: Kuntić-Makvić i Šegvić 1988. str. 50. Drugi natpis, pronađen u Dolovu kod Calića u Brgudu kod Benkovca, glasi: [Ti(berius)] Claudius Epetinus / [C(aius) AJvillius Clemens / L(ucius) Coelius Capella P(ublius)/ Raecius Libo P(ublius) Valerius / Secundus iudices dati a M(arco) Pom(peio) / Silvano leg(ato) Aug(usti) pro pr(aetore) inter r(em) [p(ublicam)] / Asseriatium et inter rem p(ublicam) Alve[ritarum] / in re praesenti per sententiam determinaverunt. Cače, 1985., str. 817. Za literaturu vidi: Kuntić-Makvić i Šegvić, 1988., str. 50. 
U prijevodu: Tiberije Klaudije Epetin, Gaj Avilije Klemens, Lucije Celije Kapela, Publije Recije Libo, Publije Valerije Sekund, suci koje je postavio Marko Pompej Silvan, Augustov propretorski legat [u sporu] među općinom Aserijata i općinom Alverita, u njihovoj prisutnosti, svojim pravorijekom odredili su [granicu].

Za pravnu analizu od velika je značenja precizna datacija natpisa u 69./70. (vjerojatnije u 70.), i to posredstvom spominjanja Marka Pompeja Silvana, koji je tih godina bio namjesnik u Dalmaciji kao propretorski Augustov legat, nakon čega se - od 71. godine - bilježi u Rimu kao curator aquarum (Kuntić-Makvić i Šegvić, 1988., str. 52-53; Thomasson, 1984., 35, br. 17:024; Elliot, 2004., 282). Taj podatak okvire pravnog razmatranja postavlja u razdoblje rimskog ranoklasičnog prava, a to je ujedno i vremenski okvir za sagledavanje instituta i pravnotehničkih izričaja pripadnih izvansudskom rješavanju sporova.

\section{POČETAK RJEŠAVANJA SPORA I OSNIVANJE SUDA}

Naznaku o osnivanju suda u ovoj konkretnoj stvari čini izričaj iudices dati a Marco Pompeio Silvano legato Augusti pro praetore. Prema tome, petoricu sudaca u sporu svojom administrativnom odlukom postavio je namjesnik provincije Dalmacije. Izričaji koji sadržavaju iudex datus, tj. u množini iudices dati (ovisno o tome je li odlučivao pojedinac ili povjerenstvo), održavaju ustaljenu i tehničku formulu koja se u rimskom pravnom nazivlju, pogotovo na epigrafskim svjedočanstvima, gotovo beziznimno koristila kada se željelo naglasiti da se suci u sporu nisu postavljali voljom stranaka, nego odlukom javne vlasti - provincijskih magistrata različita ranga. Jednaki izričaji zabilježeni su na znatnom broju terminacijskih natpisa iz Dalmacije, čime dosljedno potvrđuju opisanu praksu, ali i mogućnost da se ona oblikovala temeljem kava cirkulirajućega epigrafskog predloška. Natpisi to većinom bilježe kao iudex datus, ${ }^{4}$ iudices dati, ${ }^{5}$ iudicem dare, ${ }^{6}$ a spominje se i ex auctoritate imperatoris Vespasiani iudex datus. ${ }^{7} \mathrm{U}$ literaturi koja ga razmatra s epigrafskoga gledišta takav početak natpisa smatra se jednom od inačica službenih izričaja na terminacijskim natpisima kojima je započinjao arbitražni proces o razgraničenju (Kuntić-Makvić i Šegvić, 1988., str. 51).

Bitno drugačije okolnosti od onih s akta o razgraničenju Aserije i Alverije iščitavaju se iz izričaja nekoliko dalmatinskih terminacijskih natpisa u kojima se navodi iudex ... ex conventione datus. ${ }^{8}$ Potonji izričaji upućuju da su suci, doduše, postavljeni odlukom javne vlasti, ali da je pritom magistrat sankcionirao prethodni sporazum stranaka o podnošenju spora na rješavanje te njihovu izboru iudices. Ogledan primjer takve prakse čini izričaj finis ... secundum conventionem

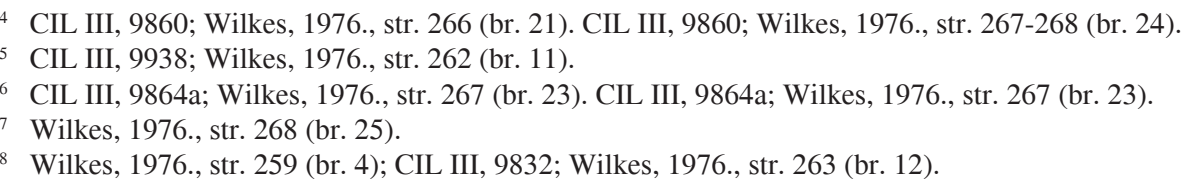


utriusque partis ... iussu Auli Duceni Gemini legati Augusti pro praetore na natpisu o razgraničenju između peregrinskih zajednica Ansienses i Corinienses. ${ }^{9} \mathrm{Iz}$ potonje skupine izvora proizlazi i sljedeći zaključak: ako su stranke ex conventione odredile rješavanje spora, tada su imale određenu slobodu kod izbora iudices, ali uz pretpostavku da rimska provincijska vlast u Dalmaciji takav izbor naknadno potvrdi.

Za razliku od znatnog broja drugih terminacijskih natpisa u Dalmaciji, u razgraničenju Aserije i Alverije nije zabilježena vrsta namjesnikova akta kojim je pokrenuto rješavanje spora i osnivanje suda, nego je zabilježen tek opći izričaj iudices dati koji naznačuje da je namjesnik sâm postavio suce. U određenom broju natpisa iz Dalmacije izrijekom je zabilježena i vrsta magistratova akta (Milotić, 2018., str. 322). Tako se navodi da su suci postavljeni ex decreto Publii Cornelii Dolabellae legati pro praetore (Wilkes, 1976., 258 (br. 1), str. 259 (br. 3.)), ex edicto P. Cornelii Dolabellae (CIL III 9973; ILS 5953; Wilkes, 1976., str. 265 (br. 16)), ob decretum Aurelii Galli legati (CIL III 3167, 8663, 14239; Wilkes, 1976. , str. 265 (br. 16)).

Najčešće se kao akt kojim su imenovani suci i osnovan sud bilježi zapovijed (iussum) provincijskoga magistrata, primjerice, iussu A. Duceni Geminis (CIL III 2883, 15045; Wilkes, 1976., str. 260 (br. 7), 262 (br. 8)), iussu (?) legati Caesari Augusti Germanici (Wilkes, 1976., str. 262 (br. 10)), iussu Luci Volusi Saturnini legati pro praetore (CIL III 8472; Wilkes, 1976., str. 265 (br. 17)), Bassus legatus Augusti pro praetore ... iudicare iussit (Wilkes, 1976., 266 (br. 20)), Lucius Funisulanus Vetonianus legatus pro praetore pontem et terminos renovari iussit (Wilkes, 1976., str. 266-267 (br. 21)).

F. F. Abott i A. C. Johnson u dosada najobuhvatnijem djelu o rimskoj upravi opisani mehanizam rješavanja sporova odredili su pojmom administrativna arbitraža zbog toga što ga pokreće i nadzire provincijski upravni aparat (Abott i Johnson, 1926., str. 158). T. Elliott opće obilježje postupaka dokumentiranih na terminacijskim natpisima izrazio je shvaćanjem da se radi o procesima s privatnim modus operandi i obligatornim značajkama (Elliot, 2004., str. 20), što podrazumijeva da stranke nisu imale utjecaj na pokretanje rješavanja spora i osnivanje suda, dok su u nekim iznimnim slučajevima mogle utjecati na izbor arbitara. Na primjeru natpisa iz Histonuma (CIL IX, 2827), koji pokazuje znatne analogije s natpisom koji je predmet ovoga rada, Elliot je glede načina rješavanja spora ustvrdio sljedeće: ... handled privately by binding arbitration ... (Elliot, 2004., str. 20).

Osim iudex datus, na natpisu o razgraničenju Aserije i Alverije nema naznaka o tome da su stranke u sporu ikako sudjelovale u izboru iudices. Razmjerno pouzdano može se zaključiti da je svu petoricu na temelju svojega imperija designirao namjesnik provincije. S obzirom na to, analogno jednom starijemu shvaćanju koje je glede izvansudskog rješavanja sporova u 19. stoljeću izrazio C. Weizsäcker (Weizsäcker, 1879., str. 52), petorica iudices u ovome sporu mogu se okvalificirati

9 U prijevodu: Kameni međaš postavljen je prema sporazumu stranaka utemeljenom na zapovijedi Aula Ducenija Gemina. Wilkes, 1976., 262 (br. 9). 
kao iudices necessarii (tj. prinudni suci), za razliku od iudices voluntarii, čiji bi izbor i postavljanje u većoj mjeri bili posljedica odlučivanja i sporazumijevanja stranaka u sporu. Opisane okolnosti naglašavaju da je postupak rješavanja spora za Aserijate i Alverite bio prinudan, $\mathrm{tj}$. da su oni autonomnom odlukom rimske provincijske vlasti bili uvučeni u rješavanje spora. Iz arheološke literature koja analizira tijek vojnih događanja u to vrijeme proizlazi da je 69. ili 70. godine uprava u Dalmaciji bila civilna jer se odatle prethodno premjestila XI. legija, čime je provincija ostala prazna (vacus) od znatnije vojne prisutnosti (Kuntić-Makvić i Šegvić, 1988., str. 53). Taj podatak važan je ne samo s povijesnoga, nego i s pravnoga gledišta, jer predstavlja jednu od naznaka da su petorica spomenutih iudices bili civili i da su u sporu djelovali bez vojnih prerogativa, što upućuje da rješavanje spora nije provela vojska, pa samim time nije postojala potreba da prinudnost njegova rješavanja bude izražena do krajnosti - uključivanjem vojske.

Izražena prisilnost rješavanja spora između Aserije i Alverije otkriva beskompromisnu namjeru Rimljana da se on riješi. Činjenica da je baš namjesnik provincije (magistrat najvišega ranga na tome teritoriju), u konkretnom slučaju postavio iudices, što se izrijekom spominje na natpisu, dodatno potvrđuje navedeno shvaćanje. Položaj provincijskoga namjesnika kakav se iščitava s ovoga natpisa odražava izrazito proširene (apsolutne) ovlasti te magistrature nakon uvođenja Carstva, a s obzirom na koje je on postao najvažniji službenik u državi na području izvan grada Rima. U određenoj mjeri to se može pripisati i izraženom statusu ovdašnje provincije kao carske zbog njezine problematičnosti, ali i općom politikom Rima da se nakon 23. godine sve osnovane provincije kvalificiraju carskima (Lowenstein, 1973., str. 259). S druge strane, premda je rimska vlast in ultima linea i na prisilan način odlučila pribjeći rješavanju spora te je u tu svrhu postavila iudices, osnovala sud i odredila da granično pitanje između tih dviju peregrinskih zajednica treba cjelovito ${ }^{10}$ riješiti, ni na ovome natpisu, kao ni na drugim takvima iz Dalmacije, ne iščitava se da su Rimljani išta zadali ili odredili glede samoga načina rješavanja spora i kako će se to operativno postići (modus operandi). Čini se da je Rimljanima od prvotna interesa bilo da se spor o granici između dvaju plemena riješi, ali im pritom nije bilo od važnosti kako će se to učiniti. Premda je to mogla učiniti, rimska vlast nije se željela neposredno miješati u takve sporove niti u njih intervenirati na način da ih jednostrano riješi administrativnom odlukom. Opisane okolnosti jednako se i beziznimno iščitavaju iz svega terminacijskoga gradiva iz provincije Dalmacije. U takvim pobudama i razlozima ogledaju se težnje Rimljana da, odmah nakon pacifikacije nemirnih zajednica, u Dalmaciji uspostave dugotrajno održiv i stabilan sustav rimske vlasti te čvrst upravno-teritorijalni okvir, ali i da uklone sve zapreke tome (Dzino, 2010., str. 156, 159, 166; Milotić, 2018. str 331-332). Neovisno o tome kada su i kako nastali, posebno ako su stranke bile snažne plemenske zajednice s dugim kontinuitetom poput res publicae Aseriatium

10 Kako tri spomenuta terminacijska natpisa (koji - nota bene - imaju analogne sadržaje i bilježe isti predmet) potječu s tri sasvim različite lokacije, može se razabrati kako se razgraničenje Aserije i Alverije nije provodilo na jednoj spornoj točki, nego uzduž čitave granice, zbog čega smo skloni zaključiti da se u ovome sporu granično pitanje rješavalo cjelovito. 
et Alveritarum, koje su kontrolirale velika i nepristupačna prostranstva te su otprije imale izraženu samobitnost $\mathrm{i}$ vlastite pravne režime (u natpisu nagoviješteno naznakom res publica), njihovi granični sporovi zasigurno su mogli biti latentne opasnosti za nesmetano rimsko vladanje. A. N. Sherwin-White osvrnuo se na domorodne zajednice na istočnoj obali Jadrana ustvrdivši da su one prije rimskoga osvajanja bile snažne, s dugom tradicijom samouprave i dugovjekim vlastitim tradicijskim pravnim režimima koji su odražavali njihovu posebnost (SherwinWhite, 1973., str. 252-253). U tome zasigurno treba tražiti glavni razlog rimskih nastojanja da se njihovi sporovi riješe, pa i u konkretnom slučaju granično pitanje između Aserije i Alverije.

\section{POVJERENSTVO ZA RJEŠAVANJE SPORA}

Iudices na ovome natpisu očigledno nemaju nikakvu poveznicu s iudex privatus iz drugog dijela tada u Rimu prevladavajućeg postupka per formulas. Oni su ovdje djelovali u peteročlanu povjerenstvu i izvan sudskog ili drugog institucionaliziranog procesa. Sasvim različito osobno podrijetlo petorice iudices (Kuntić-Makvić i Segvić, 1988., str. 53-56) potvrđuje da su izabrani te prigodno (ad hoc) postavljeni na tu dužnost od namjesnika provincije a da nisu ranije među njima postojale poveznice niti su se prije toga pojavljivali u takvoj ulozi, a ni njihova imena nisu bila dijelom kakva album iudicum. Izričaj natpisa, kako je rečeno, upućuje da su oni bili direktno a pro praetore constituti te da stranke na njihov izbor nisu imale utjecaj. U literaturi katkad se takvi iudices nazivaju arbitrima (Abott i Johnson, 1926., str. 158), ali takvima koje nisu imenovale stranke pa bi onda i arbitraža koja proizlazi iz njihova imenovanja trebala imati obilježja prinudnosti (prisilnosti/obligatornosti). Veći broj iudices sam po sebi upućuje na arbitražu jer je u sudskom postupku per formulas sudio iudex unus, dok se u arbitražama koje su vremenski podudarne sa sporom o razgraničenju Aserije i Aalverije spominje više arbitara (primjerice, Plinius, Epistulae 5, 1). Drugdje se osobe s analognim položajem i funkcijama u postupcima izvansudskog rješavanja spora prigodno nazivaju iudices, ali ne takvima kakvi se susreću u postupku per formulas, nego sasvim osobitim adjudikatorima koje postavlja javna vlast pa čitav postupak ima obilježja javnopravnosti. Za takva pojedinca "Vocabularium iurisprudentiae Romanae" navodi da je a magistratu datus, tj. datus a praetore vel proconsule secundum ordinem iudiciorum ius dicente. ${ }^{11}$ Njega diskrecijski postavlja magistrat da djeluje kao arbitar u postupku stavljajući pred njega precizno određen zadatak. Prema mišljenju većine znanstvenika, utjecaj stranaka na njegov izbor te suglasnost ili pristanak na to nisu bili bitni niti su se zahtijevali (Frier, 1985., str. 244; Kelly, 1976., str. 125-128; Kaser, 1966., str. 43; Broggini, 1957., str. 9-11; Abott i Johnson, 1926., str. 158). Iudices s natpisa o razgraničenju zasigurno su morali imati neka posebna znanja, vještine, iskustvo,

11 U prijevodu: Arbitar kojega je postavio pretor ili prokonzul sudi prema pravilima sudskoga postupka. Vocabularium iurisprudentiae romanae, tom. 1, fasc. 3, 485. 
razumijevanje stvari i dr. potrebne za pravilno rješavanje konkretna spora o granici. Glagol determinaverunt naznačuje da je u trenutku njihova imenovanja provincijski namjesnik pred iudices stavio precizan i konkretno određen zadatak - utvrđivanje razgraničenja, $\mathrm{tj}$. međa (finis determinatio). To potvrđuje i arheološka situacija, $\mathrm{tj}$. podatak da se spomen razgraničenja između Aserije i Alverije pojavljuje na trima natpisima pronađenima na tri različite lokacije, što upućuje na utvrđivanje granice u dugoj liniji.

Drugi važan podatak s natpisa jest postojanje povjerenstva od neparna broja iudices. Problematiku parnog ili neparnog broja osoba koje su u povjerenstvu rješavale spor na primjeru arbitraže ex compromisso raspravili su klasični pravnici te su njihova shvaćanja, kako zbog vremenske podudarnosti tako i sadržajno, ali i svojom ratio primjenjiva na ovaj slučaj. Ako su stranke izabrale više arbitara, njihov je broj u rano i srednje klasično doba mogao biti paran i neparan. Ograničenja nisu postojala. Ipak, paran broj arbitara sa sobom je povlačio mogućnost pojave teškoća u odlučivanju ako su se shvaćanja arbitara o predmetu spora razilazila i podijelila tako da nije bilo većinskoga mišljenja. Probleme koji nastaju kao posljedica imenovanja parnog broja arbitara spominje Ulpijan u fragmentu u Digesta koji propituje broj arbitara, ali samo u arbitražama ex compromisso. Stranke su imale mogućnost izbora parnog ili neparnog broja arbitara, ali je u kasno klasično doba pretor izrijekom suzbijao takav izbor propter naturalem hominum ad dissentiendum facilitatem, pa stoga non quoniam consentire omnes facile est (Ulpianus, D.4.8.17.6.). Natpis o razgraničenju Aserije i Alverije datira u rano klasično doba pa ostavlja mogućnost provincijskom namjesniku da glede imenovanja učini kakogod želi. K tome, zbog njegova širokog imperija u provinciji, on nije bio vezan postojećim pravnim shvaćanjima (Lowenstein, 1973., str. 259). U sporu između Aserije i Alverije provincijski namjesnik vjerojatno se povodio praktičnom logikom odmah imenovavši neparan broj arbitara. I taj podatak nagoviješta namjesnikovo inzistiranje da se spor riješi bez ikakvih zapreka - u ovome slučaju takvih koje bi mogle biti posljedica imenovanja parnog broja iudices. U rimskim izvorima poznati su i drugačiji obrasci imenovanja neparnog broja arbitara. Tako Plinije (Mlađi) bilježi mogućnost imenovanja jednog arbitra koji sâm naknadno priziva još dvojicu (Plinius, Epistulae 5, 1). Radi suzbijanja parnog broja arbitara moglo se predvidjeti treću osobu koja će zatim imenovati još jednog (Ulpianus, D.4.8.17.5).

Podrijetla petorice iudices, ali i slijed te ratio njihova spominjanja jednog iza drugoga, znakoviti su glede očuvanja objektivnosti i nepristranosti prilikom odlučivanja. Povjerenstvo je bilo mješovita sastava. Prvo (Tiberije Klaudije Epetin) i trećespomenuti (Lucije Celije Kapela) bili su stranci koji nisu živjeli na području gdje se provodilo razgraničenje. Stoga oni u povjerenstvu predstavljaju izvanjski element (Kuntić-Makvić i Šegvić, 1988., str. 56). Njihove rimske ili cjelovito romanizirane onomastičke formule navode na to da ih je namjesnik provincije kao svoje pouzdanike imenovao iz središnjeg upravnog areala želeći time zadržati kontrolu nad radom povjerenstva. Znakovito je i da se te izvanjske osobe spominju $\mathrm{u}$ prvome dijelu popisa petorice iudices. I drugospomenuti iudex (Gaj Avilije Klement) bio je strana podrijetla, ali je bio nastanjen na teritoriju zajednica među 
kojima se razgraničenje provodilo pa je u tome smislu bio došljak. Od petorice iudices tek su dvojica bila liburnijskoga podrijetla (Publije Recije Libon i Publije Valerije Sekund). Premda o tome ne postoje podaci, može se pretpostaviti da je jedan pripadao Aseriji, a drugi Alveriji. Posebno je znakovita činjenica što su dvojica liburnijskih (domaćih) iudices zabilježeni na pretposljednjem i posljednjem mjestu (Kuntić-Makvić i Šegvić, 1988., str. 56).

Takav redoslijed spominjanja petorice iudices nije slučajan. On upućuje na promišljeno strukturiranje komisije, razotkriva specifičnu konstelaciju interesa i utjecaja u njoj, ali i optimalnu ravnotežu između onoga što je rimsko i vladajuće (prva trojica iudices, tj. većina) i biljega lokalnosti i podređenosti (dvojica posljednjih iudices, tj. manjina). Namjesnik provincije u peteročlano povjerenstvo postavio je trojicu svojih pouzdanika - rimskih građana, čime je većinskim brojem članova pridržao kontrolu rimskih vlasti nad procesom te je u svim zamislivim ishodima osigurao donošenje odluke. Time je, ujedno, osigurao nepristranost odlučivanja. Uključivanjem osoba liburnijskoga podrijetla, s druge strane, osigurao je uključenost predstavnika stranaka, a time i lokalnog elementa u spor postigavši to da su Aserijati i Alveriti barem u nekoj mjeri osjećali rješavanje spora svojim, tj. da se ne događa u cijelosti bez njih ili mimo njih. Potonje čini tipično obilježje arbitara i arbitraže (Martino, 1986., str. 27-28; Broggini, 1957., str. 40, 111; Greenidge, 1901., str. 39). Može se naslutiti da je naznačenim sastavom povjerenstva provincijski namjesnik želio osigurati donošenje održive, pravedne i svima prihvatljive odluke o razgraničenju jer, u krajnjoj liniji, premda on nije imao znatniji interes glede toga kakva će ona sadržajno biti, sigurno je želio da njezinim donošenjem bude uspostavljen mir i otklonjena svaka prijetnja tome. U arheološkoj literaturi susreće se održiva tvrdnja da je prvospomenuti iudex bio čelnik povjerenstva, a da je trećespomenuti bio njegov pobočnik (obojica su stranci). Drugospomenuti je iudex kao stranac nastanjen na području gdje se razgraničenje provodilo (tj. došljak) "vrlo pogodno predstavljao, angažiranu, lokalnu i objektivnu, stranu komponentu" (Kuntić-Makvić i Šegvić, 1988., str. 56). To je i ratio njegova stavljanja na drugo mjesto na popisu.

Premda je inskripcija izrađena na čistom latinskome jeziku i uz dosljedno korištenje epigrafskih kratica te tipična rimskog pravnog nazivlja (što odražava snažan rimski utjecaj), opisane okolnosti glede podrijetla iudices ostavljaju sasvim izvjesnom mogućnost da se postupak operativno nije u cijelosti vodio na latinskome, nego na kakvom lokalnom jeziku ili govoru koji su razumjeli pripadnici obiju plemenskih zajednica (Roebuck i De Loynes de Fumichon, 2004., str. 177). Predmet i cilj ovoga postupka, koji se sastoji u finis determinatio, dodatno otvara tu mogućnost jer je pitanje granice i njezino obilježavanje graničnim znakovljem stvar koja umnogome ovisi o mjesnim prilikama i tradicijskome razumijevanju stvari, a u čemu rimski element nije bio od važnosti, već onaj plemenski.

Osim niza pravnih argumenata da su petorica iudices bili arbitri (a dokumentirani postupak zapravo arbitraža), jednaka shvaćanja zastupljena su i u epigrafskoarheološkim razmatranjima. Tako B. Kuntić-Makvić i M. Segvić spomenute iudices 
nazivaju "petoricom opunomoćenika namjesnika provincije $s$ funkcijom arbitara pri teritorijalnom razgraničenju" (Kuntić-Makvić i Śegvić, 1988., str. 51, 52, 58). ${ }^{12}$

\section{STRANKE U SPORU}

Epigrafski su stranke u sporu naznačene izričajem ... inter rem publicam Asseriatium et rem publicam Alveritarum, što upućuje da se radi o dvije susjedne peregrinske zajednice jednaka ranga (res publicae) i da su na ravnopravnoj osnovi pristupile uređivanju granica svojih teritorija. Dok je označavanje stranaka u sporu nužno i stoga zabilježeno na svim terminacijskim natpisima iz Dalmacije, natpis o razgraničenju Aserije i Alverije izdvaja se od svih time što su jedino na njemu stranke okvalificirane kao res publicae (Milotić, 2011., str. 224). Prema tome, natpis sadržava etnonim stranaka (Asseriatium i Alveritarum), ali on dodatno te jedinstveno na natpisima iz Dalmacije spominje njihov rang kao res publicae. $\mathrm{Na}$ ostalim natpisima dalmatinske provenijencije stranke su naznačene samo etnonimom (primjerice, Ortoplini, Parentini, Corinienses, Salviates, Stridonenses i dr.). Stoga taj podatak ima važnost za izvođenje zaključka da su, u odnosu na druge plemenske (peregrinske) zajednice u Dalmaciji koje su spoznate s terminacijskih natpisa, zajednice Aserijata i Alverita iz rimske perspektive kasnih 60-ih godina 1. stoljeća imale pravno prepoznat stanoviti pravni rang, a time i subjektivitet. Za razliku od ostalih zajednica koje su spomenute tek etnonimom (koji svjedoči samo o njihovu faktičnom postojanju), za te dvije zajednice Rimljani su imali potrebu dodatno naznačiti da je riječ o res publicae, što je u svojoj biti pravna kvalifikacija.

Premda se oznaka neke zajednice kao res publica često dovodi u svezu s municipium, što je u najvećemu broju slučajeva održivo, može se ustvrditi da svaka res publica nije samim time i municipium, ali da svaki municipium jest res publica (Canning, 2003., str. 124-125, 195-197; Crawford, 1995., str. 427430). Pojam res publica bio je pravno dovoljno široko postavljen da obuhvati raznovrsne entitete različitih stupnjeva relevantnosti i subjektiviteta, pa se pod tim pojmom u klasično doba spominju colloniae, municipia, civitates, ali i collegial corpora. U ranopricipatsko doba, dok je Rim doživljavalo ekspanziju taj je pojam bio odgovarajući i za označavanje peregrinskih zajednica (Iavolenus, D.3.4.8.; Ulpianus, D.48.18.1.7.; Duff, 1938., str. 37). To potvrđuje i primjer aserijatske i alveritske zajednice čija se oznaka res publica ne dovodi u svezu s municipalnim rangom, nego se kvalificira kao oznaka autohtone zajednice kojoj je rimska vlast $u$ sustavu provincijske uprave ostavila i priznala određeni stupanj autonomije. Još je bolje to zamjetno na primjeru Aserije, čija je antička povijest dobro dokumentirana, a izvori upućuju da je u ranu principatu bila prosperitetna i romanizirana peregrinska zajednica dobro povezana prometnicama s drugim dijelovima Dalmacije, ali bez dokazana statusa municipija. ${ }^{13}$

12 To čine držeći se De Ruggiera, 1886-1912, vol. 1, fasc. 2, s. v. arbiter; vol. 3, fasc. 1, s. v. fines.

13 Čače, 1985., str. 771-772; Kuntić-Makvić i Šegvić, 1988., str. 56-57; Čače, 2003., str. 7-36; Čače, 2008., str. 19-28. 
U takvom pravno-povijesnom kontekstu izričaj res publica na ovome natpisu treba tumačiti kao oznaku peregrinske sa stanovitim stupnjem samoupravne autonomije koji je ostavljen kao izričaj obzira Rimljana prema snažnim zajednicama duga kontinuiteta i tradicije koje su obuhvatili granicama svoje države. Taj obzir prema aserijatskoj i alveritskoj samoupravi zasigurno je bio izraženiji negoli u slučaju drugih plemenskih zajednica, što je rezultiralo pridavanjem relevantnosti tako što ih se naslovilo kao res publicae. I taj podatak dovoljno govori o namjerama Rimljana koji zasigurno nisu imali cilj uništiti snažne i velike zajednice domorodaca s kojima su se susreli prilikom osvajanja, već posvjedočuje suprotno - da su nastojali očuvati ono malo od autonomije što im je ostalo nakon Bellum Batonianum i njihova uključivanja u sustav provincijske uprave, pa čak to i proširiti (Sherwin-White, 1973., str. 58, 72-73; 252-253; Dzino, 2010., 156, 159, 166; Milotić, 2011., 225226; Milotić, 2018., str. 334-335).

Naznakom res publica za obje stranke u konkretnom sporu apriorno se proklamira njihova ravnopravnost, ali i sposobnost da budu procesni subjekti. Takva kvalifikacija može biti i naznaka da je rješavanje toga spora u većoj mjeri "rimsko", negoli u sličnim sporovima drugih zajednica označenih samo etnonimom. Potonjemu u prilog može ići podatak da su trojica od petorice iudices vjerojatno bili rimski građani (ili u najmanju ruku snažno romanizirane osobe), na što upućuje njihova onomastička formula. Na izraženiji "rimski" element dodatno upućuje besprijekornost korištenja latinskoga nazivlja i epigrafskih kratica. Ipak, ako se usporedno razmatraju sama bit i način rješavanja spora između Aserije i Alverije $\mathrm{s}$ jedne te među drugim zajednicama s druge strane, ne opaža se razlika s obzirom na svojstvo ili rang stranaka koji su drugačije izraženi, tj. s obzirom na to jesu li označene kao res publicae ili samo etnonimom. U procesnom smislu to je bilo samo nominalno (izričajno) razlikovanje koje bi možda u nekoj drugoj pravnoj sferi moglo imati veće značenje (u smislu naznake jačega subjektiviteta, izgrađene osobnosti, samoupravne autonomije ili barem obzira rimskih vlasti u postupanju s res publicae).

\section{PROCES RJEŠAVANJA SPORA IZMEĐU ASERIJE I ALVERIJE}

Premda se na natpisu ne spominju finis, confinium, terminus ili druge oznake za granicu, izričaj inter rem publicam Asseriatium et rem publicam Alveritarum te nadovezujući per sententiam suam determinaverunt, kao i in re praesenti, dovoljni su da se bez sumnje može ustvrditi da se radi o graničnom sporu. To dodatno potvrđuje činjenica da je razgraničenje zabilježeno na trima natpisima $\mathrm{s}$ triju različitih lokacija prilikom čega linija među tim lokacijama predstavlja granicu između Aserije i Alverije.

Sporovi poput ovoga najčešći su među peregrinskim zajednicama, ali i municipia te coloniae u svim dijelovima Carstva (Campbell, 2000., 454-467) te o 
njima, ali i o obilježavanju granične linije znakovljem nakon provedena procesa, postoji velik broj izvora (Campbell, 2000., 472-474). I na području Dalmacije ta vrsta sporova izrazito prevladava u ukupnoj strukturi natpisa iz ranoga principata: (1) ...[finis] inter Begi et Ortoplinos...; (2) ...finis inter Ortoplinos et Parentinos, aditus ad aquam vivam...; (3) ... finis inter Neditas et [?]...; (4) Finis inter Neditas et Corinienses...; (5) ...finis inter Ansienses et Corinienses...; (6) Termini positi inter prata legionis [...?] et fines roboreti Flavii Marciani per Augustianum Bellicum procuratorem Augusti; (7) ...inter Onastinos et Narestinos terminos posuit...; (8) ...inter Nerastinos et Pituntinos termini recogniti et restituti, ...diceret sententiam de ponendis terminis; (9) ...pontem et terminos renovari iussit...; (10) ...fines regeret et terminus poneret; (11) ...fines inter Salviatas et Stridonenses determinavit; (12) ...[fines] secundum Formam Dolabellianam restituit...; (13) Finis inter Seium severinum centurionem cohortis VIII voluntariorum et Baebidium TitIanum rigore rivi. ${ }^{14}$

S procesnoga gledišta važna je naznaka da su iudices bili in re praesenti kada su per sententiam suam determinaverunt. Iz toga se iščitava da su sva petorica bila osobno prisutna izricanju pravorijeka, što je prepoznatljivo obilježje arbitraže. Kad god postoje naznake u rimskome pravu da je vijeće odlučivalo u sporu koji se rješavao izvansudski, zahtijevalo se, osim ako stranke same nisu što drugačije ugovorile, da izricanju pravorijeka osobno prisustvuju svi arbitri (Ulpianus, D.4.8.7.1.; Ulpianus, D.4.8.17.2.; Ulpianus, D.4.8.17.2.; Pomponius, D.4.8.18.). Ako svi imenovani arbitri ne bi zajedno sudjelovali u odlučivanju i solidarno donosili odluku, ${ }^{15}$ pravorijek je bio ništav (Ziegler, 1971., str. 123). Kako je u utvrđeno da Aserijati i Alveriti nisu imali utjecaj na izbor iudices, jer se rješavanju spora pribjeglo neovisno o njihovoj volji, zasigurno nisu utjecali ni na način postupanja i odlučivanja. Podatak da su iudices u ovome slučaju bili in re praesenti treba tumačiti tako da su oni tome prisustvovali prvotno jer je to u takvom za njih prisilnom postupku rješavanja spora od njih zahtijevala rimska vlast.

Na terminacijskim natpisima iz Dalmacije ponegdje se pojavljuje pravni tehnički izričaj consilio adhibito (athirito consilio CIL III, 8472; adhibito consilio CIL III, 8473) koji upućuje da je pravorijek izrečen nakon održana sastanka ili nakon

14 (1) ...granica između Bega i Ortoplina...". Wilkes, 1976., str. 258 (br. 1); (2) ...granica između Ortoplina $i$ Parentina $i$ pristup živoj vodi... CIL III, 15053; Wilkes, 1976., str. 258-259 (br. 2); (3) ...granica između Nedita i...? Wilkes, 1976., str. 259 (br. 3) i str. 260 (br. 5); (4) Granica između Nedita $i$ Korinienza... CIL III, 2883; (5) ... granica između Anziena and the Korinineza... Wilkes, 1976., str. 262 (br. 9); (6) "Granično zankovlje postavljeno je između legionarskih livada i hrastika Flavija Marciana odlukom Augustijana Belika, Augustova prokuratora CIL III, 13250; Wilkes, 1976., str. 264 (br. 14a-b); (7) ...postavljeni su granični znakovi između Onastina i Narestina CIL III, 8472; (8) ...između Nerastina i Pituntina utvrđeno je i obnovljeno granično znakovlje... CIL III, 12794; (9) ...donijeti pravorijek o postavljanju graničnog znakovlja Wilkes, 1976., str. 266 (br. 20); (9) ...naredio je obnovu mosta graničnog znakovlja Wilkes, 1976., str. 266-267 (br. 21); (10) odrediti granicu i postaviti granično znakovlje CIL III, 9864a; (11) ...određena je granica između Salviata i Stridonenza CIL III, 9860; (12) Granicu je utvrdio prema Forma Dollabeliana Wilkes, 1976., str. 268 (br. 26); (13) Granica između zemljišta Seja Severina, centuriona Osme kohorte i Bebida Ticijana usporedo s riječnim tokom CIL III, 3163; Wilkes, 1976., str. 268 (br. 27).

15 Ziegler tu vrstu arbitraže naziva kollegiales Schiedsgericht, a način imenovanja arbitara solidarische Ernennung. Ziegler, 1971., str. 123. 
vijećanja. Taj izričaj uvijek podrazumijeva odlučivanje u vijeću, kao što je slučaj na natpisu koji se analizira. Spomenuti izričaj ustaljen je u pravnom nazivlju, a otprilike u isto vrijeme kada je nastao natpis o razgraničenju Aserije i Alverije te dva potonja dalmatinska natpisa pojavljuje se u pismu Plinija Mlađega upućena Aniju Severu u kojemu opisuje nasljednopravni spor koji su izvansudski rješavala trojica arbitara. U Plinijevu se pismu navodi da su trojica arbitara (sâm Plinije, Kornelije i Frontin) bili in consilium adhibiti (Plinius, Epistulae 5, 1,6) te da su tako, svi zajedno, donijeli pravorijek (Roebuck i De Loynes de Fumichon, 2004., str. 62-63; Ziegler, 1971., str. 159-161; Kaser, 1966., str. 28, 40, 58).

Držeći se epigrafskog argumenta (in re praesenti i consilio adhibito), zatim spomenuta Plinijeva pisma i, napokon, opće naravi terminacijskih sporova koji su se gotovo beziznimno rješavali u arbitraži i zahtijevali neposrednost arbitrova opažanja i izvođenja dokaza (najčešće na samoj graničnoj liniji; Campbell, 2000., str. 468-471), vjerojatno su petorica iudices s natpisa o razgraničenju Aserije i Alverije zajedno prisustvovali i poduzimanju svih procesnih radnji. Iz usporedivih izvora proizlazi da je rješavanje graničnih sporova uvijek podrazumijevalo obilazak cijele linije, a posebno spornih točaka, poduzimanje očevida, uvid u katastre i očevidnike stvarnih prava, traženje starijih (uništenih, pomaknutih, oštećenih i dr.) tragova demarkacije i obavljanje izmjere. ${ }^{16} \mathrm{U}$ tome smislu granični su sporovi, osim pravne, imali izraženu tehničku dimenziju, što je od iudices nužno zahtijevalo neku vrstu kvalifikacije. Stoga su u razgraničenjima sudjelovale i vojne osobe (što je dokumentirano i u Dalmaciji) u čijemu su se krugu lakše pronalazili pojedinci s odgovarajućim znanjima i mjeriteljskim vještinama jer ih je vojska nužno morala imati. ${ }^{17}$ Sudjelovanje vojnih osoba kao arbitara u takvim postupcima dodatno je bilo uvjetovano i time što su iussum za pokretanje rješavanja spora gotovo beziznimno izdavali vojni službenici u Dalmaciji, što je u ovome radu prethodno razloženo. Međutim, za petoricu iudices u razgraničenju Aserije i Alverije sigurno je da su bile civilne osobe, što navodi na zaključak da su, povrh već spomenutih svojstava uvjetovanih svojim podrijetlom, morale biti izabrane i zbog kakve druge faktične kvalifikacije, primjerice iskustvene, poznavanje terena ili graničnog problema i sl.

Rezultat konkretnog procesa bio je finis determinatio, tj. utvrđivanje međe, što neposredno proizlazi iz natpisne naznake da su iudices ... [finem] determinaverunt. I taj glagol izražen u 3. 1. pl. potvrđuje da su sva petorica iudices zajednički utvrđivala granicu i da su o tome na koncu odlučili svojim pravorijekom (per sententiam suam). Pravorijek nije donio ni pojedinac niti samo neki od njih petorice, nego svi zajedno premda ga je, držeći se logike, usmeno izrekao samo jedan od njih,

16 Primjerice, Scaevola, D.4.8.44; Ulpianus, D.10.1.8.1.; Cassiodorus, Variae 3, 52, 8; Codex Iustinianus 3.39.3.1. Vidi: Ziegler, 1971., str. 83. Dokumentiran je slučaj iz 1. stoljeća (vremenski podudaran s natpisom o razgraničenju Aserije i Alverije) na natpisu iz Histonuma u kojemu je arbitar supstancirao pravorijek nekim starim opisom (očevidnikom) međa koje su bile predmet spora (CIL IX, 2827). Vidi: Campbell, 2000., str. 475-477. Za izmjeru prilikom rješavanje graničnog spora u Dalmaciji vidi: CIL III, 2887 (Milotić, 2018., str. 334).

17 Iz Dalmacije potječe natpis (CIL III, 2883) koji bilježi da su Aulo Resije Maksim, posterior centurion u Prvoj kohorti Devete legije, i Kvint Ebucije Liberal utvrdili granicu držeći se provedene izmjere koju je naložio Aulo Ducenije Gemin, carski legat pretorska ranga. 
vjerojatno Tiberije Klaudije Epetin - koji je prvi spomenut na popisu iudices pa stoga vjerojatno i svojevrsni antestatus.

Finis determinatio, a posebno nadovezujući pojam sententia, odražavaju precizno i dosljedno korištenje tehničkoga nazivlja poznatog iz rimskoga prava. Sa strogo formalnog gledišta, institut sententia obično se koristi za označavanje odluke (pravorijeka) u arbitražnim postupcima kao opreka iudicium, koji većinom označava odluku u sudskome postupku (Paulus, D.4.8.19.1.; Roebuck i De Loynes de Fumichon, 2004., str. 20-21). U postupcima poput ovoga, u kojima se uopće ne odlučuje o tome tko je u pravu, a tko u krivu, njezina je funkcija i narav prevladavajuće regulacijska. Na to upućuje i promišljeno korištenje glagola determinare - na natpisu se navodi da su suci nešto utvrdili (iudices determinaverunt), a ne da su presuđivali stvar (iudicaverunt), kao što je - primjerice - izrijekom zabilježeno na natpisu o sporu između Barizaniata i Lizaviata (Wilkes, 1976., str. 266 (br. 20); Elliot, 2004., 113). S druge strane, finis determinatio nije bio tek tehnički posao bez značajnije pravne supstancije poput termina ponere, restituere, recognoscere ili renovare i sl. S finis determinatio sadržajno je podudaran izričaj fines regere koji je u Dalmaciji zabilježen na CIL III, 9864a. Potonji natpis izričajem fines regeret et terminus poneret naznačuje bitnu razliku između pravnog regulacijskog posla koji se sastoji u fines regere i naknadnog čisto tehničkog posla - postavljanja znakovlja na tako utvrđenu granicu (terminos ponere).

I na primjeru razgraničenja Aserije i Alverije, posebno u tome što je razgraničenje utvrđeno na najmanje tri točke s kojih potječu tri natpisa, potvrđuje se rječničko podrijetlo naziva sententia, $\mathrm{tj}$. da ono dolazi od arbitrova neposredna čulna opažanja (sentire $\rightarrow$ sententia) svih odlučnih činjenica u sporu. Pojmovna i etimološka odrednica latinske riječi sententia pokazuje da je ona izvedenica od glagola sentire, a sentire potječe od riječi sin koja označava osjetilo, čulo. Sententia je stoga realizacija sentire, tj. ona je proklamacija o onome što je osoba neposredno osjetila svojim čulima (Moussy, 1999., 20-23; Realencyclopädie der classischen Altertumswissenschaft, 1923., str. 1496, 1498-1499).

Može se postaviti pitanje ima li pravorijek (sententia) donesen u sporu između Aserije i Alverije javnopravna ili privatnopravna obilježja. Posljedično, to nameće i pitanje je li izvršenje pravorijeka ovisilo samo o dobroj volji stranaka. U aktu pokretanja postupka i osnivanja arbitražnog suda ističe se javnopravni element $u$ osobi provincijskoga namjesnika koji u tu svrhu sâm postavlja iudices (iudices dati). Nakon njihova postavljanja, petorica iudices djeluju kao arbitri, ali uz zamjetnu kontrolu koju namjesnik ostvaruje posredstvom barem trojice njih koji su stranoga podrijetla. Cini se da je autoritativnu legitimaciju pravorijek imao u aktu kojim je provincijski namjesnik osnivao sud i pokretao rješavanje spora. U takvim okolnostima nije zamislivo da su Aserijati ili Alveriti smjeli zanemariti pravorijek, a da se pritom ne izlože prisili javne vlasti. S obzirom na iudices dati koje je postavio namjesnik provincije, općepoznati izostanak appellatio do uvođenja cognitio extra ordinem u 3. stoljeću, ali i nepostojanje pravnih lijekova u izvansudskim načinima rješavanja spora (Milotić, 2013., str. 241-248), sa sigurnošću se može ustvrditi da 
je pravorijek petorice iudices bio konačan te da nije bio podložan relativizaciji, izmjenama, ispravcima ili naknadnim osporavanjima.

Tri terminacijska natpisa o razgraničenju Aserije i Alverije potječu s graničnog znakovlja koje je postavljeno nakon izricanja sententiae. Oni su opredmećenje usmeno izrečena pravorijeka, i to kako u smislu da je znakovlje postavljeno na točno određene točke temeljem utvrđenja u procesu, tako i u smislu da ono sadržava izreku sententiae koja je očuvana kao zapis (inskripcija). Klesanje usmeno proklamiranog pravorijeka i postavljanje kamena predmeta na točno određeno mjesto trebalo je javnim i neprolaznim učiniti bitna utanačenja glede spora: iudices, stranke, njegov predmet, čin pokretanja i način kako je rješavanje spora provedeno te pravorijek. To naznačuje da je razgraničenje koje je provedeno pravorijekom iz 69./70. godine između Aserije i Alverije bilo važeće kroz dulje vrijeme i da se ono uzimalo u obzir u odnosima tih dviju peregrinskih zajednica.

\section{ZAKLJUČAK}

Na temelju svega razloženoga mogu se potvrditi navodi (Kuntić-Makvić i Šegvić, Elliot) koji proces razgraničenja između Aserije i Alverije kvalificiraju kao arbitražu. Zbog njezine prinudnosti, in casu concreto najbolje je taj proces po Abottovu i Johnsonovu uzoru okvalificirati administrativnom arbitražom ili, držeći se Elliota, prisilnom arbitražom. Iudicia divisoria (koja se sastoje od utvrđivanja i uređivanja granica te podjele zemljišta) redovno su se i gotovo beziznimno razrješavala u arbitražama, i to kako u Italiji tako i u provincijama. Takav trend u čitavom rimskom pravu ustaljen je i dobro dokumentiran, a izgrađivao se od Zakonika XII ploča (Romac, 1994., str. 133; Gaius, Institutiones 4,17a). Kako je i razgraničenje Aserije i Alverije čisti iudicium divisorium, is toga gledišta proizlazi da je ovdje riječ o arbitraži te da su petorica iudices zapravo arbitri.

Daljnji argument da je riječ o arbitraži proizlazi iz ad hoc naravi konkretnog procesa i suda koji je odlučivao. Sud je osnovan aktom provincijskog namjesnika utemeljena na njegovu imperiju, čime su postavljeni arbitri. Jednom kada su donijeli sententia kojom su fines determinaverunt, ta petorica prestala su biti arbitri, a sud je prestao postojati (functus officio). Dakle, sud je osnovan ad hoc i una causa, što naočigled odudara od institucionalizirana procesa i predstavlja tipično prigodno obilježje arbitraže. To sa sobom povlači konačnost pravorijeka jer, jednom kada je bio donesen, zbog prestanka postojanja suda, više nije bilo tijela koje bi moglo odlučivati ili na njega ikako utjecati. Osobe koje su odlučivale o razgraničenju bile su ad hoc delegirane od javne vlasti. To nisu osobe čija su imena bila upisana na kakvoj listi iz koje bi onda vlast izabirala pojedince za potrebe konkretnog spora. Zbog njihovih različitih svojstava i iz raznovrsnih pobuda, te je osobe javna vlast designirala samo jednom, i to u konkretan spor, a kada je bio riješen, vraćale su se prijašnjemu životu, što također odražava obilježja arbitraže. 
Znakovita je činjenica da su stranke ravnopravno sudjelovale u sporu i da su njihove procesne pozicije bile jednake, što se dijelom održava i u njihovu jednakom naslovljavanju kao res publicae. Dakle, među njima ne postoji tužitelj (actor) i tuženik (reus) ili suprotstavljeni interesi kao u parnici, niti arbitri odlučuju o tome tko je u pravu, a tko u krivu. U tome procesu jednako se u obzir uzimaju argumenti i interesi obiju stranaka glede razgraničenja pa je čitav proces razgraničenja istovremeno i pravni i tehnički, ali prvotno regulacijski. I u tome se nazire znatna razlika prema suđenju, ali i obilježje arbitraže čiji se pravorijek u konkretnom slučaju ne sastoji u osudi ili dosudi, nego u utvrđenju, tj. regulaciji (determinatio).

Napokon, treba se osvrnuti i na pravno nazivlje. Koriste se precizni nazivi i izričaji koji odražavaju ustaljene procesne institute rimskoga prava u 1. stoljeću. Međutim, kada se u kontekstu toga natpisa uzmu u obzir svi zajedno, ali i držeći se usporednih primjera iz Dalmacije i drugih provincija, primjećuje se da oni odražavaju pojmovnik koji prevladavajuće pripada arbitraži. Stoga ne preostaje drugo negoli potvrditi kako je u slučaju razgraničenja Aserije i Alverije riječ o slučaju prisilne (obvezujuće/obligatorne) arbitraže.

\section{LITERATURA}

1. Abott, F. F. i Johnson, C. A. (1926.) Municipal Administration in the Roman Empire. Princeton: Princeton University Press.

2. Broggini, G. (1957.) Iudex Arbiterve, Prolegomena zum Officium des römischen Privatrichters, Köln - Graz: Böhlau.

3. Campbell, B. (2000.) The Writings of the Roman Land Surveyors - Introduction, Text, Translation and Commentary, London: Society for the Promotion of Roman Studies.

4. Canning, J. (2003.) The Political Thought of Baldus de Ubaldis, Cambridge: Cambridge University Press.

5. Crawford M. H. (1995.) "Roman towns and their charters: Legislation and experience". U: Social Complexity and the Development of Towns in Iberia, Barry Cunliffe i Simon Keay (ed.), Proceedings of the British Academy, 86, (421-430), Oxford: British Academy.

6. Čače, S. (1985.) Liburnija u razdoblju od IV. do I. st. prije nove ere, neobjavljena doktorska disertacija, Zadar: Filozofski fakultet.

7. Čače, S. (2003.) "Aserija u antičkim pisanim izvorima". Tekstovi i komentari. U: Asseria, 1, Ivo Fadić, Slobodan Čače (eds.), (7-43), Zadar: Arheološki muzej u Zadru.

8. Čače, S. (2008.) "Aserija, rimske ceste i Plinijevi podatci". U: Asseria, 6, Ivo Fadić, Slobodan Čače (eds.), (11-28), Zadar: Arheološki muzej u Zadru.

9. De Ruggiero, E. (1886-1912) Dizionario epigrafico di antichità romane, vol. 1, fasc. 2, vol. 3, fasc. 1, Rim: L. Pasqualucci.

10. Duff, P. W. (1938.) Personality in Roman Private Law, Cambridge: Cambridge University Press. 
11. Dzino, D. (2014.) "The formation of early imperial peregrine civitates in Dalmatia: (Re)constructing indigenous communities after the conquest". U: Marko A. Janković, Vladimir D. Mihajlović, Staša Babić (eds.), Imperialism and Identities at the Edges of the Roman World. (215-227). Newcastle upon Tyne: Cambride Scholars Publishing.

12. Elliot, T. (2004.) Epigraphic Evidence for Boundary Disputes in the Roman Empire, neobjavljena doktorska disertacija, Chapell Hill: University of North Carolina.

13. Frier, B. W. (1985.) The Rise of the Roman Jurists: Studies in Cicero's pro Caecina, Princeton: Princeton University Press.

14. Greenidge, A. H. J. (1901.) The legal procedure of Cicero's time, Oxfoerd: Oxford Univeristy Press.

15. Kaser, M. (1966.) Das Römische Zivilprozessrecht, München: C. H. Beck Verlag.

16. Kelly, J. M. (1976.), Studies in the civil judicature of the Roman Republic, Oxford: Clarendon Press.

17. Kuntić-Makvić, B. i Šegvić, M. (1988.) "O razgraničenju između Aserije i Alverije". $\mathrm{U}$ : Arheološki radovi i rasprave, 11 (1988.), 49-62.

18. Lowenstein, K. (1973.) The Governance of Rome, The Hague: Martinus Nijhoff.

19. Martino, P. (1986.) Arbiter, Rim: La Sapienza.

20. Milotić, I. (2011.) "Roman Boundary Stones in Croatia: Legal Content and its Forms in Acts of Dispute Resolution". U: Inszenierung des Rechts - Law on Stage, Viktoria Draganova, Stefan Kroll, Helmut Landerer, Ulrike Meyer (eds,), (217-232), München: Martin Meidenbauer.

21. Milotić, I. (2013.) "Exclusion of Appeals against Arbitration in Roman Law". U: Croatian Arbitration Yearbook, 20, 241-248.

22. Milotić, I. (2018.) "Peregrine communities in Dalmatia at the beginning of the 1st century from perspective of their disputes". U: The century of the brave: Roman conquest and indigenous resistance in Illyricum during the time of Augustus and his heirs / Stoljeće hrabrih: Rimsko osvajanje i otpor starosjedilaca u Iliriku za vrijeme Augusta i njegovih nasljednika, Marina Milićević Bradač, Dino Demicheli (eds.), (331-342), Zagreb: FF Press.

23. Moussy, C. (1999.) "Les vocables latins servant à designer le sens et la signification". $\mathrm{U}$ : Conceptions latines du sens et de la signification, Marc Baratin i Claude Moussy (eds.), (13-27), Pariz: Presses Paris Sorbonne.

24. Realencyclopädie der classischen Altertumswissenschaft (1923.), 2. ser., Band 2A, Halbband 4, Georg Wissowa (ed), Stuttgart: J. B. Metzlersche Buchhandlung.

25. Roebuck, D. i De Loynes de Fumichon, B. (2004.) Roman Arbitration, Oxford: Holo Books.

26. Romac, A. (1994.) Zakonik dvanaest ploča, Zagreb: Latina et Graeca.

27. Smodlaka-Kotur, A. (1990.) "Nepravni epigrafski spomenici - izvor za rimsko pravo". U: Zbornik radova Pravnog fakulteta u Splitu, 27(2), 31-45.

28. Thomasson, B. E. (1984.) Laterculi Praesidum, vol. 1: ex parte retractatum, Göteborg: Radius. 
29. Wilkes, J. J. (1976.) "Boundary Stones in Roman Dalmatia". U: Arheološki vestnik, 25 (1976.), 258-274.

30. Ziegler, K.-H. (1971.) Das private Schiedsgericht im antiken römischen Recht, Münchener Beiträge zur Papyrusforschung und antiken Rechtsgeschichte 58, München: C. H. Beck Verlag.

\section{KRATICE}

$\mathrm{CIL}=$ Corpus inscriptionum latinarum

D. $=$ Digesta

\section{ARBITRATION IN BOUNDARY DISPUTE BETWEEN ASERIA AND ALVERIA}

Three inscriptions found in Dalmatia record a boundary dispute between the tribal communities of Aseria and Alveria. These inscriptions record the relevant facts that were associated with that particular dispute and circumstances in which the dispute resolution was achieved. They refer to the legal institutes and typical legal expression that the Romans often employed in dispute resolution which was achieved outside courts and institutionalized legal proceedings. With regard to the content of the inscription, the author analyses the procedural institutes and preconditions that had to be fulfilled for the successful dispute resolution, for example, court and its constitution, selection of arbitrators, parties to the dispute, disputed subject-matter, taking the procedural actions and the decision by which the dispute was ended. On the grounds of previous epigraphic studies and archaeological contextualisation the boundary dispute between Aseria and Alveria is here appreciated from the legal point of view, with an emphasis to the identification of exact meaning of the legal terms that were employed and with reference to the relevant institutes of Roman law at the time being (early classical Roman law). The analysis is provided with regard to the peculiarity of the provincial administration in Dalmatia, especially to the position and imperium of the provincial governor at that time, as well as with reference to the boundary disputes that the other Dalmatian tribal communities had among themselves. The intention of the Romans becomes apparent to resolve such disputes and thereby to eliminate all the potential dangers and obstacles for the stabile provincial governance. The inscriptions reveal that the boundary dispute was decided in arbitration, though, not in a regular one, but rather in a proceeding which was not voluntary for the parties, because it was unilaterally imposed by the provincial governor himself. For this reason, that particular dispute resolution should be qualified as an administrative arbitration with evident mandatory characteristics.

Key words: arbitration, boundary dispute, inscription on boundaries, Dalmatia, Roman law 